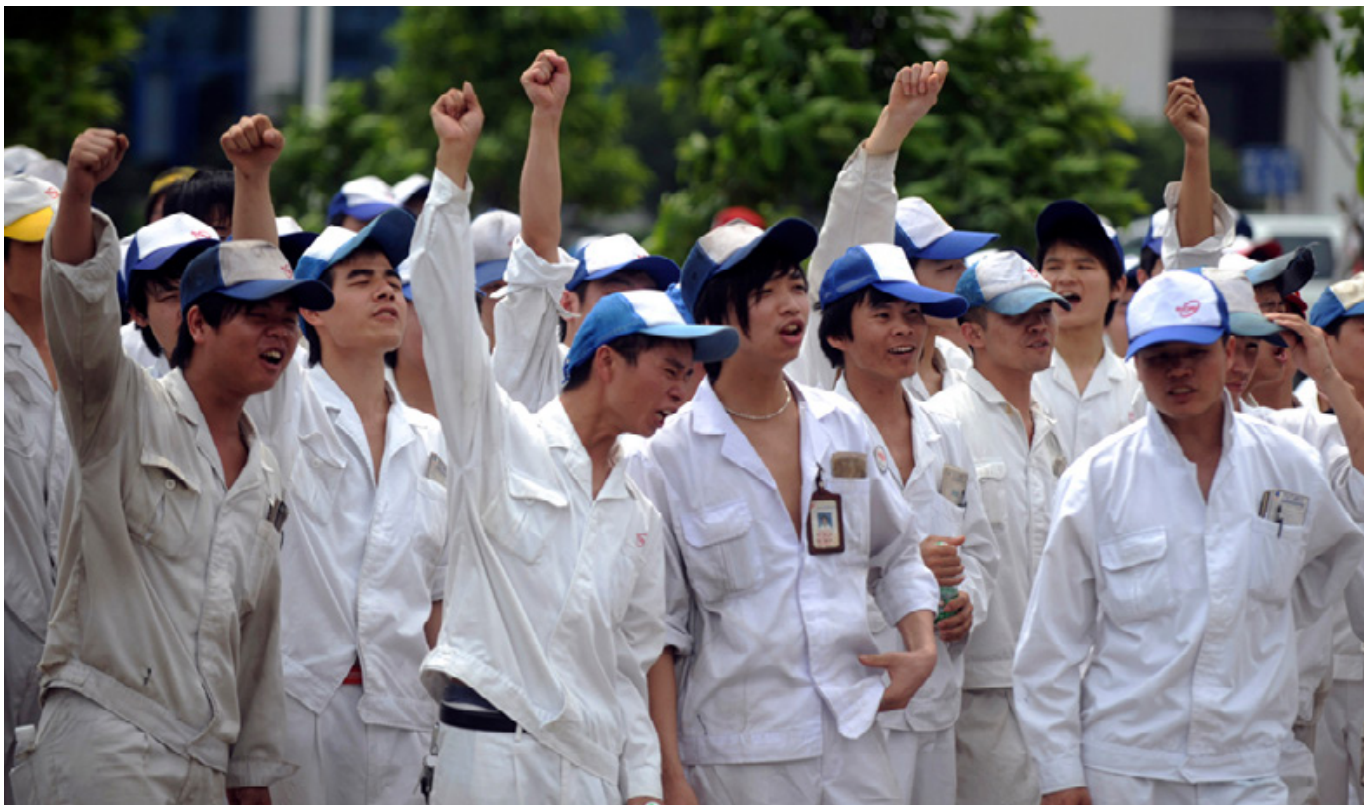

\section{Changes and Continuity}

Four Decades of Industrial Relations in

\section{China}

\section{Chris King-Chi Chan}

China's economic reforms started exactly forty years ago. Labour scholars today are debating the extent to which labour relations and the labour movement in China have changed, and where they may be heading. Positions are polarised between pessimists who emphasise the structural power of the market and the authoritarian state, and optimists who envision the rise of a strong and independent labour movement in China. In this essay, Chris King-Chi Chan advocates for a different approach.
June 2010, workers at Foshan Fengfu Auto Parts Co. a supply factory to Honda Motor's joint-ventures in China, strike to demand higher wages. PC: People's World/AP.
We year 2018 marks the fortieth anniversary of the beginning of China's economic reform programme initiated in 1978. The rise of migrant workers' strikes since early 2000s and the efforts of the Chinese government to rebalance and reregulate workplace relations have created fertile ground for labour studies and labour activism in China. One of the key debates in this scholarly/activist community concerns the extent to which labour relations and the "labour movement' in China have changed, and where they may be heading. Pessimists highlight the structural power of the market and the ability of the authoritarian state to undermine worker solidarity and collective action, while optimists 
envision the ongoing emergence of a strong and independent labour movement in China, supported by labour NGOs and international civil society.

In the midst of this debate, on 3 December 2015 there was a major crackdown on labour NGOs in Guangzhou and Foshan. Between 2012 and 2015, most of the affected NGOs had been active in assisting the collective struggles of workers by promoting collective bargaining. Some labour lawyers and academics referred to this new type of NGO as 'labour movementoriented NGOs' (gongyunxing NGOs) to distinguish them from 'social service-oriented NGOs' (fuwuxing NGOs) and 'legal rightsoriented NGOs' (weiquanxing NGOs) (Duan 2015; see also Franceschini and Lin's essay in the present issue). This crackdown was a major setback for Chinese activists who had worked to build a labour movement from the ground up. For scholars, by the time their studies on labour movement-oriented NGOs were published, these organisations had essentially ceased to exist.

Does this portend a gloomy future for Chinese workers? To respond to this question, I advocate a Marxian approach built on two observations (see for example Chan 2010 and 2012; Chan and Hui 2017). First, class struggle between capital and labour around the issues of production, which is constrained by global political economy, defines the history of China's integration into global capitalism. Second, the state remains a contested terrain of class struggle in China. It is only through a workercentred and historical approach that we can understand the rapidly shifting landscape in contemporary China, and what the future may hold.

\section{Harmonious Labour Relations}

Since the early 1990s, China has established itself as a 'world factory', with the cities in the Pearl River Delta (PRD) as its powerhouse.
Major ethnographic research conducted in the PRD has found that the politics of place and gender were often exploited by management to maintain class domination and despotism throughout the 1990s (Lee 1988; Pun 2005). But labour relations have undergone change in the new millennium. Politically, after President Hu Jintao and Premier Wen Jiabao took office in 2002, a series of socioeconomic reforms reforms were introduced in the name of building a 'harmonious society' (hexie shehui). Social challenges related to farmers, rural areas, and agriculture-the so-called 'three rural problems' (sannong wenti)-have since become a greater concern for the Party-state. Economically, since 2003, China has surpassed the United States as the country with the largest foreign direct investment inflow in the world. China's GDP also shocked the world, with an average annual growth rate of 10.5 percent from 2001 to 2011 (National Bureau of Statistics of China 2012).

The dramatic changes in China's urban and rural economies since 2003 has given rise to a shortage of labour (mingonghuang)-a situation in stark contrast with the labour surplus (mingongchao) of the early 1990s. Within this context, rising waves of strikes and protests have taken place in the PRD since 2004. This unrest has forced the government to increase the minimum wage and introduce new labour laws, culminating in the 2008 Labour Contract Law. This law was intended to stabilise and regulate labour relations by making written contracts a legal obligation for employers. Workers were entitled to double pay if their employers did not sign a contract with them and, after they completed two consecutive contracts or were employed for ten continuous years, the employer was required to give them a permanent contract. Employers had to pay severance of one month's wages for each year of service if they wanted to dismiss a worker. This was an important step to the formalisation of employment relations for the migrant workers, who had previously existed in a precarious state (Lee 1988; Pun 2005). 


\section{Class Struggle Intensified}

The global economic crisis of 2008 had a major effect on the Chinese economy. In 2009, China's total exports decreased by 16 percent (National Bureau of Statistics of China 2010). Many factories in South China faced closure or bankruptcy, but the Chinese economy recovered quickly due to the government's huge stimulus investment in infrastructure and social spending. In 2010, the GDP growth rate returned to double digits (10.3 percent). Concomitant with this economic revival was the reemergence of labour shortages. Against this backdrop, a more significant wave of strikes led by Honda workers in June 2010 attracted global attention. These industrial actions gave impetus to the process of trade union reform (Chan and Hui 2014), and the All-China Federation of Trade Unions (ACFTU) began to promote a policy of wage bargaining and trade union direct election.

The next turning point for labour relations in China came in 2012, as President Xi Jinping took power. Unlike the $\mathrm{Hu}$-Wen administration which emphasised harmonious society and pursued reformist social and labour policies, Xi's government has adopted a hard-line policy to pacify labour activism. The foundation of this political change has been the economic slowdown since 2012, with many factory closures and relocations. The GDP growth rate decreased from 10.1 percent in 2011 to 8.1 percent in 2012 and 6.7 percent in $2016-$ a situation that Xi has called the 'new normal' for the Chinese economy (National Bureau of Statistics of China 2016).

Since 2012, many factories announced their relocation plans with minimal or no compensation to workers. In response, workers increasingly took collective action. During this period, pension insurance became one of the main demands of migrant workers on strike. This demand was encouraged by the Social Insurance Law, in effect since 2011, and was also pressing because many migrant workers had reached or were nearing retirement age. The strike at the Yue Yuen shoe factory in Dongguan in April 2014 was the most influential collective action concerning pension issues (Chen 2015). More than 40,000 workers went on strike for more than 10 days, gaining global attention. The strike ended with the company agreeing to pay the social insurance owed to the workers (Chan and Hui 2017). Another successful case took place at the Lide shoe factory in Guangzhou in August 2014. Lide workers were able to receive compensation and social insurance before the factory's relocation with the help of the Panyu Migrant Workers Service Center, one of the major 'labour movement oriented NGOs' (Froissart 2018).

Since then, in the face of the economic slowdown, the Party-state has lowered the standard of labour rights protection. For instance, in February 2017, Guangdong province announced that the minimum wage now would be adjusted every three years, rather than every two years, in order to lower operation costs of enterprises. Thus, the minimum wage in 2018 would remain at the 2015 level (Caixin 2017). At the same time, police intervention in labour protests escalated, strikes that affected public order could be directly shut down, and worker leaders risked arrest. Wu Guijun, one of the leaders of a strike in Shenzhen in 2013, was detained for 371 days (Mitchell 2015). Labour NGOs were also targeted by the government. This had dramatic negative repercussions for the development of labour NGOs in China, with many organisations becoming severely constrained in the ways they were able to support workers' collective actions.

\section{The Future}

The latest developments show that some labour NGOs seem to have reduced capacity to support workers in their struggle due to the shrinking political space for civil societyparticularly civil society working in the labour sphere. But challenges to labour activism do 
not put an end to class struggle. Therefore, in order to understand the trajectory of China's labour situation there are two key points that must be considered.

First, workplace conflict is embedded within the capitalist production regime. Strikes and other forms of labour protests will not be eliminated without structural change in industrial relations. In an attempt to smooth over the contradictions and strengthen the existing system, in recent years the Chinese Party-state has made great effort to reform local trade unions, and to strengthen their capability to intervene in workplace conflict and promote collective bargaining. One example is the pilot project of the Shenzhen Federation of Trade Unions to establish community-based worker service centres and worker training programmes (Dou 2017). If these projects are successful, an authoritarian hegemonic labour regime will emerge in some sectors and regions, but at least workers will enjoy slightly better protections. If, on the contrary, the state-led reformist policies are not well implemented and detrimental working conditions remain, the workers' struggle will carry on.

In fact, the dramatic growth of the service sector in China has resulted in surging labour unrest in relevant industries. Workers' collective actions in the service industries have accounted for 21 percent of all collective action cases, surpassing the manufacturing industries for the first time in the third quarter of 2016 (China Labour Bulletin 2016). Information about labour strikes and protests are generally more difficult to access. Still on May Day of 2018, the Global Times, an official Chinese newspaper, reported that crane operators in the construction sector had launched protests across China demanding better pay and an eight-hour working day. In the city of Chengdu alone, at least 10,000 workers joined the protest (Yin 2018).

Second, regarding the role of NGOs, it should be noted that they are a tool, rather than the goal, of civil society in supporting workers. Historically, labour NGOs in the PRD were initiated by Hong Kong labour organisations, activists, and academics (Chan 2018). In the late 1990s and early 2000s, with the more relaxed policies of the Party-state, labour activists and intellectuals in mainland China began to establish their own organisations. In this way, the existence and organisation of labour NGOs can be seen as emerging from a particular historical and political moment. As long as intellectuals and social activists maintain their concerns for labour issues, the measures they take to support the workers struggle can vary across time and space. For instance, eight university students from Beijing were detained or wanted by the government as they organised a reading group with workers in a university campus in Guangzhou (Chuang 2018). This instigated an enormous outpouring of support from Chinese scholars and other intellectuals. It illustrates that the struggle around labour rights between pro-labour civil society actors and the state is far from dead. It is ongoing, developing, and changing. Under a new political context, new strategies have been created to support workers and resist pressure from the state. 